\begin{tabular}{c} 
Volume and Issues Obtainable at Center for Sustainability Research and Consultancy \\
Journal of Accounting and Finance in Emerging Economies \\
ISSN: 2519-0318 ISSN (E) 2518-8488 \\
Volume 6: Issue 3 September 2020 \\
CSRᄃ \\
Journal homepage: www.publishing.globalcsrc.org/jafee \\
\hline
\end{tabular}

\title{
Grade Inflation and Human Capital Accumulation among Pakistani University Students
}

\author{
${ }^{1}$ Anwar Ul Haq, ${ }^{2}$ Sadaf Mahmood, ${ }^{3}$ Zahira Batool, ${ }^{4}$ Muhammad Shabbir \\ ${ }^{1} \mathrm{PhD}$ Scholar, Department of Sociology, GC University Faisalabad, Pakistan, Haqanwar11@ gmil.com \\ ${ }^{2 \& 4}$ Assistant Professor, Department of Sociology, GC University Faisalabad, Pakistan, \\ sadaf.mahmood88@yahoo.com, drmshabbir@gcuf.edu.pk \\ ${ }^{3}$ Professor, Department of Sociology, GC University Faisalabad, Pakistan, batoolazam@ hotmail.com
}

\begin{tabular}{ll}
\hline \multicolumn{1}{c}{ ARTICLE DETAILS } & ABSTRACT \\
\hline $\begin{array}{l}\text { History } \\
\text { Revised format: August } 2020 \\
\text { Available Online: September } 2020\end{array}$ & $\begin{array}{l}\text { The central objective of current study was exploring the level of school } \\
\text { acquired human capital. To understand the human capital and grade inflation, } \\
\text { 2 Focus Group Discussions (FGDs) were conducted. To measure school } \\
\text { based human capital students were asked to write an essay on a given topic. }\end{array}$ \\
\hline $\begin{array}{l}\text { Keywords } \\
\text { Grade Inflation, Quality of } \\
\text { education, Human capital, writing } \\
\text { skills }\end{array}$ & $\begin{array}{l}\text { These essays, FGDs and a brief questionnaire about background constituted } \\
\text { the data for this study. This data was analyzed using mixed-methods content } \\
\text { analysis. Data analysis generated four important themes related to human } \\
\text { capital that are Grade inflation and quality of learning, General Knowledge } \\
\text { abilities, Presentation and coherence and Writing skills. It was found that }\end{array}$ \\
$\begin{array}{l}\text { performance of students with CGPA more than group mean perform like } \\
\text { JEL Classification } \\
\text { I23, I25 }\end{array}$ & $\begin{array}{l}\text { those below the group mean. The mean values of group CGPA were also } \\
\text { high as 3.46 for Punjab University and 3.77 for Government college }\end{array}$ \\
& $\begin{array}{l}\text { University Faisalabad. The content analysis disclosed that similar mistakes } \\
\text { are made by students in both categories. This raised serious reservations on } \\
\text { the human capital of the students. This also shows the problem of grade } \\
\text { inflation. In order to overcome these problems assessment systems, need } \\
\text { reforms where actual capabilities of the students can be measured. }\end{array}$
\end{tabular}

\section{OPEN ACCESS}

(C) 2020 The authors, under a Creative Commons AttributionNonCommercial 4.0

Corresponding author's email address: drmshabbir@gcuf.edu.pk

Recommended citation: Haq, A., Mahmood, S., Batool, Z., \& Shabbir, M. (2020). Grade Inflation and Human Capital Accumulation among Pakistani University Students. Journal of Accounting and Finance in Emerging Economies , 6(3), 747-751

\section{Introduction}

Scholars vary on definition of human capital. It dates to Adam Smith (Kucharčíková, 2011) however, contemporary work on human capital was begun by Theodore Schultz. In $1981 \mathrm{He}$ defined human capital as innate and acquired skills of a person form his/her human capital (Schultz, 1961). In another study human capital was defined as the intelligence, skills, and expertise of human beings in the organization. This capital is the human component of an organization and gives it a distinctive character. Davenport defined it as people's natural abilities, nurtured abilities, behaviors, and personal energy which they bring to the workplace 
with them (Davenport, 1999). Current definition of human capital combines all these features. It is defined as skills, knowledge, experiences, abilities, and other characteristics that are essential for economic activity. human capital can be categorized into two types. One, the capital accumulated in the school and second, life cycle human capital. This study explores the human capital accumulated in the universities. Higher educational institutes play a vital role in formation of human capital. Higher education has become an essential component in contemporary societies. Sociology of higher education evaluates educational processes in universities and their influence on society and vice versa (Gumport, 2007). Higher education is increasing globally as well as in Pakistan. This increase in the number of institutions, students and workforce employed by higher education institutions (HEIs) has a huge effect on socio-economic structure of the society (Tight, 2019). Universities are not only important for sociologists to understand because of their size, but also because they produce human capital, scholarship in various fields and often provide the teachers, who then socialize the younger generations, which has a tremendous impact on society. Keeping this ubiquity and need of higher education in context, social scientists of various fields are concerned about the quality of education, systems of assessment and learning standards (Brimble, 2016). This concern is globally shared, but in Pakistan, when combined with other factors the situation demands a thorough investigation. Questions related to quality of university education are always part of "rhetoric of education reforms" (Hoodbhoy, 2009; Akhtar, Rafi, Ahmed, \& Rauf, 2011). Concerns related to quality of education, often generate discussions related to quality of human capital produced by the universities. This argument is prominent in debates, research papers, newspaper articles and electronic media (Hoodbhoy, 2015; Academia, 2019; Murti, Leghari, Battacharya, Mayana, \& Atta, 2012). These two concerns blend with each other and are referred to in the same vein.

Higher education plays a vital role in development of human capital. By providing knowledge, skills, habits, and values higher education enables the students for the workforce (Becker, 1993). Considering the importance of human capital development and tertiary education's role in it, "quality of education" is always a matter of concern. Literally, every education related newspaper article, television program, academic discussion, and educational workshop, refer to the worsening quality of learning in our universities (Hoodbhoy, 2009). Concerns related to employability (Academia, 2019), skills and abilities (Hoodbhoy, 2015) subject Knowledge (Zubair, 2018) civic sense (Hussain, 2007) and General Awareness and creativity (Raza, Mehmood, \& Jaleel, 2019) all resonate with human capital. So, worries related to quality of education are basically uncertainties about human capital produced by the universities. There are multiple factors behind this disadvantaged situation, which include but are not limited to shortage of funds and resources (Higher Education Commission, 2019), access to university education (Qutoshi, 2015), lack of good quality faculty, poor system of assessment, disadvantaged location, digital divide, poor infrastructure of universities, quantity of universities, and overcrowded classrooms bureaucratic hurdles etc. Besides all these problems a major problem that emerged in the last few years is grade inflation. Grade inflation in simple words is defined as an "increase in grades of students without an increase in the performance". This means that students acquire grades for the performance which does not deserve those marks or not deserved in the past (Merriam Webster, 2020). As the basic purpose of assessment is to test the knowledge, understanding and learning, subject matter and rank the students (Baker \& Strout, 2017). Grade inflation becomes a problem for education systems as higher marks are achieved for lower performance in all these skills. Students who are ranked higher by the universities are not well equipped with adequate skills that are demanded of that credential (Slavov, 2013). Higher education is a great step towards development of human capital. In the institutes of higher education, students accumulate knowledge, skills and habits that are useful for the economy and country at large. Tertiary education also called higher education has a positive relationship with national development as well as with human capital development. More will be the human capital and Tertiary education; national development will be more (Olayiwola, Dada, \& Olawale, 2016). This trend is reflected in various studies and even if other background factors are checked human capital has its influence towards positivity.

\subsection{Education System in Pakistan}

As Pakistan got independence from Britain in 1947, its education system was almost similar to Britain. Still Pakistani education system follows the trend. There are various stages of education in Pakistan. It begins 
with primary schooling until class five. Then comes the matric or secondary school certificate (SSC) which is equal to O-level in the Cambridge system. The education till matric is called school education. After that for two years there is college education. Colleges offer Higher Secondary School Certificate (HSSC) which is equal to A-level in the Cambridge system. For both the SSC and HSSC there are designated boards of education in every division of each province. After the completion of higher secondary education there are two streams of education. One is universities which offer two-year or four-year degrees. While the other stream is colleges which offer two-year degree programs and four-year degree programs. These colleges are affiliated with universities. So, technically all degrees are awarded by the universities. Colleges mostly offer two-year degree programs while Universities offer four years degree programs. In Pakistan requirements for most of the prestigious government jobs are usually 16 years of education. Education for MS and $\mathrm{PhD}$ are offered at university level.

\subsection{Objectives}

There were two primary objectives of the study

1. To assess the quality of human capital produced by the universities

2. To understand grade inflation among students from their performance on human capital

\section{Methodology}

This research uses qualitative methods of Focus group discussion as a source of data collection. Data related to students' human capital and grade inflation was collected using a creative approach. Students were asked to fill a brief background questionnaire and write an essay of six lines on "rivers in Pakistan". As there are five main rivers in Pakistan and this information is taught to students at different levels, so familiarity with this topic is an indicator of general knowledge. Similarly, this writing will highlight students' writing abilities, task understanding and academic integrity. These focus group discussions were conducted with students from three universities. The data collected from two universities was combined into a single file with students CGPA, Gender and academic integrity. This Data was analyzed using mix methods content analysis. Content analysis was applied to essays to identify the problems in students writing. Codes that were developed from data provided the themes. Important themes related to problems that emerged were writing skills, general knowledge skills, presentation skills and coherence skills.

\section{Data Analysis and Discussions}

The process of data analysis began with transcription of data and compilation of data into a single file. The content analysis yielded four key themes related to human capital. One, grade inflation and quality of human capital, two, student's language abilities, three students' general knowledge skills and fourth the coherence and argument building abilities. It was found that students are weak in all these abilities.

\subsection{Grade Inflation and Quality}

Grade inflation as mentioned earlier means students acquiring more grades than they deserve. Evidence in favor of grade inflation has been reported in the previous studies. It can be seen from data that students' grades vary between 2.98 to 3.98. Only one student got the low grades of 2.98. All other students who were asked to write the essay had CGPA more than 3. It was found that there is no significant difference in writing skills and general knowledge ability between the good grade students and low-grade students. The language mistakes made by students were almost similar. One thing more that cheating behavior among the students was similar. Even good students copied from the mobile. Only 7 to 9 students observed neutrality and did not copy from any source. Even after copying students' skills with good grades and low grades were equal. The mean CGPA for Punjab University was 3.46 and mean for Government college University Faisalabad was 3.77 out of 4 . These grades automatically prove that there is grade inflation. The second problem that was identified in student's writing was "writing skill".

\subsection{Writing Skills}

During the FGDs students were asked to write a minimum six lines essay about "Rivers in Pakistan". The first analysis and transcription of these essays uncovered various language problems. This situation can be categorized into three main problems. One, lack of academic writing, two grammatical mistakes and three no 
consistency in language. The academic writing was missing. Students have no concept of academic writing. All the students were in 7 th or 8 th semester but none of them showed a comprehensive academic writing. They did not bother to create any background except for one essay. The essays began without any background and were random lines. There was no argument building. Around three students tried to build the argument in favor of Pakistan being the agricultural country. Otherwise, no other student builds any argument. These points are more elaborated in the coherence section. Second there were obvious grammatical mistakes. There were only 3 essays which did not contain any obvious grammatical mistake. As English is a second language in Pakistan, so, the problems of the second language cannot be eradicated. However, English language is taught to Pakistani students for at least 14 years in school, college, and university. After that much training and education, the writing skills exhibited by the students are questionable. It was found that students made spelling mistakes. In around 6 essays students had no concept of capitalization. Sentences in the middle have been capitalized. Almost all students lack punctuation skills. Errors related to subject-verb agreement were also found. It was also found that most students are not familiar with appropriate prepositions. However, most students used the articles in a suitable way. As many of them also copied whole sentences from the mobile phones so these skills are not important in that sense. Third problem that was found in writing was there is no consistency in writing. It was even identified that there is no consistency in spelling or English language used in Pakistan. Some students followed American spellings while others used British spelling. In this regard there was a lack of consistency. Similarly, the way words were used, and the lines were arranged, no sense of consistent and coherent writing emerged. These problems are discussed in detail below in the coherence section.

\subsection{Coherence and Presentation Skills}

As the essays were related to rivers in Pakistan, students wrote six lines in different ways. Two students wrote less than six lines. Three students wrote more than six lines. There was no coherence in almost all essays except 4 essays. For example, if the first line is about agriculture the second line contains information about river names. The third line mentions hydel resources and fourth mentions water tussle between India and Pakistan. One student even mentioned Sindh province, Sindhi cap and Ajrak also. One thing that was observed clearly is that there is no concept of self-reading or second reading among students after writing. Most essays showed that mistakes could have easily been avoided upon second reading. Three students had no concept of essay writing and wrote six separate lines copied from the mobile phone. The essays were not only a test of writing skills. They were also supposed to test the general knowledge abilities of the students. The details related to general knowledge abilities is given below.

\subsection{General Knowledge Abilities}

The essays written by students were also a reflection of their general knowledge abilities. Most students demonstrated very feeble general knowledge skills and copied from mobile or others. Around 8 students copied either from mobile phones or one another. Similarly, the interesting things were observed in the essays of those students who wrote themselves. Six students who wrote their essays on their own did not mention the names of the rivers. As there are five famous rivers in Pakistan and this information is always taught in the curriculum again and again. In this regard six students who wrote themselves did not mention names of the rivers. They only wrote essays in a general sense. Around three of them mentioned agriculture and its importance without making any context. Similarly, two students mentioned fish and traditional dresses. This clearly indicates that students lack general knowledge. Even those who mentioned these things did not refer to specific sites. Most only mentioned Indus is the biggest river in Pakistan. It was also found that even after copying 3 students wrote wrong information. One student mentioned Sindh and Punjab as rivers but suddenly realized her mistake and corrected it. Another student mentioned two names of a single river and considered them as separate. These concerns related to wrong information among those who copied from mobile highlight another problem that search skills of the students are weak. Students are less comfortable in finding knowledge even online.

\section{Conclusion}

This study focused on understanding the lack of human capital and grade inflation. The grade inflation was clearly observed among students that around 8 students out of 17 had more CGPA than the mean and those 
who had higher CGPA demonstrated equal amount of knowledge and writing skills as students with lower CGPA. Using content analysis four major themes were identified. These themes are the problems of school human capital produced by the universities. These four problems are grade inflation and quality of education. In this problem it was found that Students abilities fluctuate less with difference in grades. Second, the major theme was writing skills. Students demonstrated overall weak writing skills which contained obvious mistakes like capitalization and subject-verb agreement. Third theme identified was argument building and coherence. Most students need this skill. Finally, another indicator of human capital is ability to search independently and general knowledge. Most students fall short on the general knowledge abilities. They demonstrated weak general knowledge abilities. As more than half copied information from mobile phones, this is a sign of weak general knowledge. Overall, it can be established from the results that grade inflation is clearly present and human capital produced in terms of Language abilities and General knowledge is of impoverished quality. To overcome these problems, some of the recommendations are as below,

\section{Recommendations}

First recommendation is that Pakistan must officially adopt a system of English either British or American. In some universities British English standards are followed while at others American English is followed. Second, there is a dire need to incorporate language skills into our curriculum. Languages skills must be assessed using multiple techniques and not only written work. Written work should also be assessed using creative questioning and creative writing. Finally, students should be encouraged to visit the libraries and read materials other than course.

\section{References}

Baker, S., \& Strout, S. (2017). Using Rubrics for grading and Assessment. (pp. 1-17). Badford:

Office of Academic Assessment.

Becker, G. S. (1993). Human Capital: A Theoretical and Empirical Analysis, with Special Reference to Education (3rd ed.). Chicago: The University of Chicago Press.

Brimble, M. (2016). Why students cheat: an exploration of the motivators of student academic dishonesty in higher education. In T. Bretag, Handbook of Academic Integrity (pp. 365-382). Singapore: Springer Science+Business Media. doi:DOI 10.1007/978-981-287-098-8_58

Davenport, T. O. (1999). Human Capital: What It Is and Why People Invest It. San Fransisco: Wiley.

Gumport, P. J. (Ed.). (2007). Sociology of higher education : contributions and their contexts. Baltimore, Maryland, USA: The Johns Hopkins University Press. Retrieved 2018

Hoodbhoy, P. (2017, july 1). Pakistan's professor mafia. Retrieved 2019, from The Dawn: www.dawn.com/news/1342483

Kucharčíková, A. (2011). Human capital - definitions and approaches. Human Resources Management \& Ergonomics, 2, 60-70.

Merriam Webster. (2020, August 6). Grade Inflation. Retrieved from Merriam Webster: https://www.merriam-webster.com/dictionary/grade\%20inflation

Nazir, M. S., \& Aslam, S. M. (2010). Academic dishonesty and perceptions of Pakistani students. International Journal of Educational Management, 655-668.

Olayiwola, M. M., Dada, R. M., \& Olawale, A. R. (2016). Tertiary Education and Human Capital Development:Implication on the National Development. International Journal of Academic Research in Progressive Education and Development, 14-24. doi:10.6007/IJARPED/v5-i2/2069

schultz, T. W. (1961). Investment in human capital. The american economic review, 51(1), 2-20.

Slavov, S. N. (2013, December 26). How to Fix College Grade Inflation. Retrieved from US News: https://www.usnews.com/opinion/blogs/economic-intelligence/2013/12/26/why-college-gradeinflation-is-a-real-problem-and-how-to-fix-it

Tight, M. (2019). Higher education research : The developing feild. Bedford Square London, UK: Bloomsbury Academic. 